\title{
There is no Peace without War. DeCorations of THE UPPER LUSATian Commemoration Hall faÇade
}

\author{
No hay paz sin guerra. Decoraciones \\ DE LA FACHAdA DEL SALÓN CONMEMORATivo \\ DE Alta Lusacia
}

Marta OstrowsKa-Bies

University of Silesia in Katowice

Recibido: 31/03/2020 Evaluado: 25/05/2020 Aprobado: 27/05/2020

AвStRACT: The Upper Lusatian Commemoration Hall in which Emperor-Friedrich-Museum is placed was erected in 1898-1904, according to a design by Hugo Behr, to commemorate the two Emperors who died in 1888 - Wilhelm I and his son, Friedrich III, and to the Unification of Germany more broadly. The central hall and building's elevations were equipped with numerous sculptural decorations that created a coherent iconographic program. In this article two decoration cycles devoted to the topic of war and peace placed on the façade are analized and interpreted.

Key words: Prussia, Hohenzollern, German Empire, allegory of peace and war

RESUMEN: El Salón Conmemorativo de Alta Lusacia, en el que se encuentra el Museo del Emperador Federico fue inaugurado entre 1898-1904. Ambos edificios se diseñaron a partir de los proyectos de Hugo Behr, y conmemoran a dos emperadores: Guillermo I y su hijo Federico III, además de la unificación de Alemania. La parte central de la fachada está decorada 
con numerosos bajorrelieves esculpidos que forman un diseño iconográfico coherente. En este artículo se analizan e interpretan dos de los ciclos de estas decoraciones, relacionados con el tema de la guerra y la paz.

Palabras claves: Prussia, Hohenzollern, Imperio alemán, alegoría de la paz y la guerra

As from the establishment of the new Polish-German border, which was partly marked by the Lusatian Neisse (Pol. Nysa Łużycka), Görlitz was divided between these two countries. The right-bank part became the Polish city of Zgorzelec, the left-bank remained the German city of Görlitz, with the Old Town. Thus, the Upper Lusatian Commemoration Hall (Oberlausitzer Gedenkhalle) (fig. 1), dominating the right-bank part of the centre, is located in the former Municipal Park (Stadtpark), which spreads along the eastern bank, which belongs to the territory of the People's Republic of Poland. Fortunately, the building survived the war, and, following a brief period of being the Army premises, it has been used as the Municipal Culture Centre since 1948. Apart from the statues of the Emperors and busts of distinguished Germans, which were removed from the inside, and decorations with Prussian symbols and patriotic texts, the remaining carved decorations were maintained. The iconographic program of sculpture and reliefs, unintelligible to the average member of the Polish audience, became an integral element of the architecture, reduced to the decorative function, which was adapted to the new architectural objectives. Although in the recent years academic ${ }^{1}$ or popular science ${ }^{2}$ papers have been written about the building itself, none of the papers touches on the ideological contents of the carved decorations, restricting themselves to listing the depicted images, or rather repeating them after the source text, ${ }^{3}$ which can be inferred from the repeated inaccuracies thereof. The previous findings of the researchers, Katarzyna Czekańska in particular, based on the source and comparative materials, place the Zgorzelec building in the entire series of the 19th century

1. It discusses the collection's history and aims to analyze the relation of Upper Lusatian Commemoration Hall to analogical, museum/commemorative buildings: INES ANDER: «Die Oberlausitzer Gedenkhalle mit Kaiser-Friedirich-Museum in Görlitz 1902 bis 1932. Ein Beitrag zu Geschichte und Selbstverständnis der Städtischen Kunstsammlungen Görlitz», in Görlitzer Magazin, 1992, 6 Jhrg, pp. 1-36; genesis and the erection process of the building: ANDrEas BednAREK: «Die Ruhmeshalle - patriotisch, edel und schön Ein Beistrag zur Baugeschichte der Oberlausitzet Gedenkhalle in Görlitz», in Görlitzer Magazin, 1992, 6 Jhrg, pp. 37-49; MA Thesis on the building: KatarzynA CzeKAŃsKA: «Gmach dawnej Oberlausitzer Gedenkhalle mit Kaiser Friedrich Museum w Zgorzelcu», master's thesis under supervision of Prof. Zofia Ostrowska-Kębłowska at the Art History Institute, University of Wrocław, 2005, not published.

2. Guenter Oettel: Unter der grünen Kuppel. 1, Vom Museum in Görlitz zum Kulturhaus in Zgorzelec, 1904-2004, Taschenbuch, Görlitz-Zittau, 2004.

3. Hugo BeHR: «Die Oberlausitzer Gedenkhalle mit Kaiser Friedrich-Museum in Görlitz», in Deutsche Bauzeitung, 1903, xxxviI Jhrg, n. ${ }^{\circ}$ 61, pp. 393-394, 402-404. 
commemorative monuments erected after the Napoleonic Wars (after 1813) and the Unification of Germany (after 1871), and emphasize the local ideological motifs - the reunification of the Upper Lusatia ${ }^{4}$ within a single country in $1871 .{ }^{5}$ However, a thorough analysis, which would answer the question of how this overriding message codded in the building itself was realized through the carved decorations of the Upper Lusatian Commemoration Hall elevations, has not been conducted in the source literature yet. Therefore, this work is the first attempt at analysing and interpreting selected sculptures and reliefs placed on the building façade in the context of its overall ideological significance. ${ }^{6}$

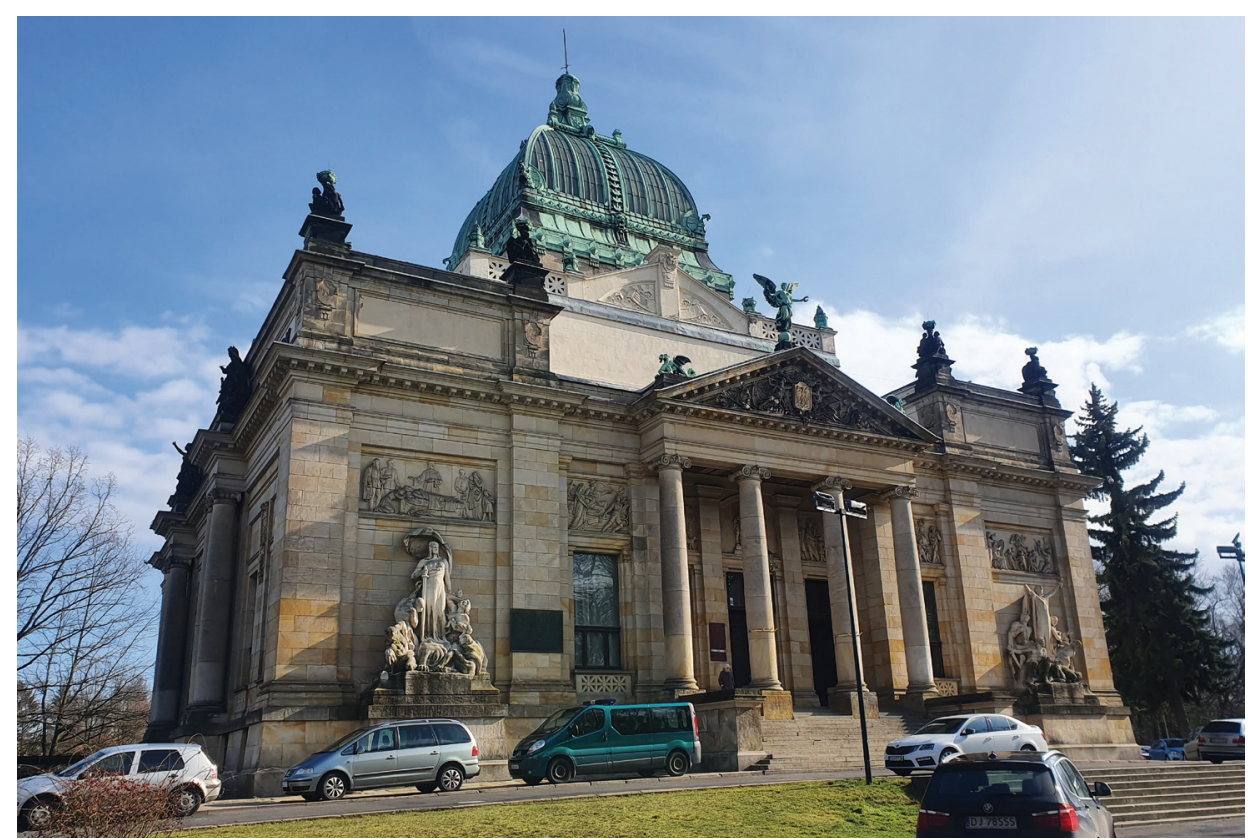

Fig. 1. Hugo Behr, Upper Lusatian Commemoration Hall with Emperor-Friedrich-Museum, façade, 1898-1904, Zgorzelec (Görlitz)

4. Following the Napoleonic Wars, under the Congress of Vienna resolution, Upper Lusatia was divided into two parties - eastern, incorporated into the Prussian province of Silesia, and western, incorporated into the Kingdom of Saxony. Reunification of the Upper Lusatian territories within a single national entity (the German Empire) took place in 1871 as a result of the Unification of Germany. Cf. Leszek Belzyt, HansWERnER RAUTENBERG: «Górne Łużyce od kongresu wiedeńskiego do końca pierwszej wojny światowej (1815-1918)», in JoAнiм Bahlcke (ed.): Dzieje Górnych Lużyc. Wtadza, społeczeństwo o kultura od średniowiecza do końca XX wieku, Wydawnictwo DIG, Warsaw, 2007, p. 203-222.

5. CZeKańsKa: op. cit.

6. Due to the extension of this article, the analysis and interpretation of all the sculptural decorations, presented both inside the building and on its elevations, was impossible. Hence the analysis was limited to two, the most important cycles: War and Peace. Other similarly interesting decorations require further research, the results of which will be included in future publications, synthesizing the topic of ideological content of the Upper Lusatian Commemoration Hall. 
The Upper Lusatian Commemoration Hall (also referred to as the Upper Lusatian Hall of Fame, (Pol. Górnołużycka Hala Chwały, Ger. Oberlausitzer Ruhmeshalle) was erected in 1898-1904, according to a design by Hugo Behr, selected in a competition. ${ }^{7}$ Although it was built by the Upper Lusatians to commemorate the two consecutive Emperors who died in 1888 - Wilhelm I and his son, Friedrich III, it was soon decided that a building combining two functions - commemorative and museal - should be erected. ${ }^{8}$ The dual purpose of the building is conspicuous in both its form and decoration.

The Upper Lusatian Commemoration Hall is a two-story building, set on a plinth, with a high ground floor and the first floor partly hidden by a high attic, and separated from the lower part with a prominent cornice. The floor plan of the entire structure is close to a square. The central part of the building interior is a presentable hall extending on both stories, which originally had functions connected with the commemoration of the Emperors and the Unification of Germany in 1871. The rooms on the ground floor and first floor, symmetrically placed around the hall, were used to display and store collections of arts, crafts and archaeological artefacts of the Upper Lusatia region. ${ }^{9}$ The most important place of the section connected with commemorating was a niche placed opposite the main entrance, decorated with a mosaic with the Sun motif, where a double statue of the Emperors by Johannes Pfuhl ${ }^{10}$ was placed. One could approach it by marble stairs topped with sculptures of lionesses lying in the position of the Sphinx, also by Pfuhl. Apart from the Emperors' statues in the hall, there were also sculptures of individuals who contributed to the Unification of Germany - six herm busts of the Federal Countries kings and princes ${ }^{11}-$ in front of the pillars supporting the gallery, and three full figures on the gallery of the first floor, opposite the Emperors' niche, but more in the background, representing Otto von Bismarck, Helmuth Karl Bernhard von Moltke and Albrecht von Roon, the so called Reichseiniger. The iconographic complement of this pantheon is constituted by four relief stone slabs presenting setting out for the war and return from the war (not preserved), allegoric presentations of wisdom and power, and wisdom and justice in bronze, painted coats of arms of the Upper Lusatia cities placed in the gallery of the first floor, as well as inscriptions on the walls.

7. The Competition Regulations and selected designs were published in: «Ruhmeshalle in Görlitz», in Deutsche Konkurrenzen, Leipzig, 1898.

8. Detailed description of the history of creating the concept and building construction BEDNAREK: op. cit., pp 37-49.

9. The history of the collection exhibited in the Upper Lusatian Commemorative Hall building in: ANDERs: op. cit., pp. 1-36.

10. More on the sculptures of the Emperors in URsula Zенм: Die Geschichte des Doppelstandbildes im deutschsprachigen Raum bis zum 1. Weltkrieg mit beschreibendem Katalog, Verlag und Datenbank für Geisteswissenschaften, Weimar, 1995, pp. 27-29.

11. On the left: King Johann von Sachsen, Grand Duke Friedrich von Baden, King Ludwig II von Bayern. On the right: King Albert von Sachsen, Grand Duke Friedrich Franz II von Mecklenburg, King Karl von Württemberg. 
The building is located on a small hill. It can be approached by one-flight stairs, intersected halfway with a crosswise driveway. The building design, as filed with the construction authority, assumed covering all the four elevations with sandstone slabs, however, it was finally decided, probably due to the growing construction costs ${ }^{12}$ and the necessity to find savings, to finish the outer walls in different ways depending on the significance of the individual views of the building. The façade and the north-eastern elevation, facing the former Friedrich Platz, are the most stately, and thus the most distinguishing ones in terms of decoration and the materials used. The other two elevations were plastered and received only a modest - rather flat - architectonical detail, corresponding with the tectonics of the building. The central part of the symmetrically composed façade features a partly deep portico supported on four Ionian columns, with the entablature above, topped with a triangular pediment with figurative decoration. It includes three door openings separated by pilasters whose overdoors are filled with reliefs, the central one of wich presents a female figure on the throne, Germania, and on her two sides there are figurative scenes described in the sources ${ }^{13}$ as "Northern Germany and Southern Germany pay homage to Germania". ${ }^{14}$ On the two sides of the portico there are high windows surrounded by simple window banding, and panneau with relief decoration, which, in terms of composition and theme, is connected with the neighbouring Germania homage motif. Each of the end bays, flanked with broad pilasters, have the form of avant-corps, which, according to the designer, resemble the pylons of Egyptian temples. ${ }^{15}$ Their elevations are decorated with two groups of sculpture by Hugo Lederer, a Berlin artist - the allegory of Peace (on the right) and War (on the left) -, for which a protruding fragment of the base course constitutes the pedestal. Over these representations there are panels with relief decoration - The Blessings of Peace (on the right) and The Atrocities of War (on the left). Together with the aforementioned decorations over the door and window openings, they form a specific frieze going around the entire width of the façade at the same height. ${ }^{16}$

12. The Competition Regulations determined the construction costs of RM 350,000. Each of the entered designs which assumed an increase of the construction expenditure was rejected by the committee as not meeting the requirements. The final cost of the construction was RM 752,000, out of which only the sculpted decorations (not entire, some as gifts) cost RM 164,600. HUGO BEHR: «Die Oberlausitzer Gedenkhalle mit Kaiser Friedrich-Museum i. Görlitz», in Deutsche Bauzeitung, 37 Jhrg, 1903, 37 Jhrg, n. ${ }^{\circ}$ 62, p. 404.

13. Ludwig Feyerabend: Führer durch die Oberlausitzer Gedenkhalle mit Kaiser Friedrich-Museum, Görlitz 1905, p. 7.

14. Although in his description of the ideological meaning of the Zgorzelec building, the author of the project characterizes the cycle as «Northern Germany and Southern Germany paying homage to Germania», the iconological content of the work is not unambiguous. Depicted figures are not allegories of certain German states, some of them seem to represent specific people (a scholar, a saint) or their personifications (a blacksmith as a personification of Bismarck). This aspect requires further research and is not covered by the context of this article.

15. BEHR: op. cit., p. 402.

16. In the design submitted to the competition the frieze ran continuosly through the side elevation, for which a portico - analogous to the facade - was designed. 
All the frieze decorations, the Victory bronze figure at the fronton topping, the allegories of Art and History at the north-eastern façade, and the figurative sculptures of a lamp post at the attic topping are made by Reinhard Schnauder, a Dresden sculptor. The listed above decorative elements of the façade were already included in Behr's competition project. Perhaps, at this stage not only their arrangement, but also their semantic program was determined. This can be implied by the sketch filling left, end panel (later repeated on the design submitted to the Building Bureau in Görlitz) showing an analogy in composition with Schnauder's bas-relief, which can be found here ("horrors of War") and in the motif of Victoria, crowning the fronton of the portico.

The seven-axis north-eastern elevation, alike the façade, has a symmetrical composition predominated by vertical divisions in the form of corner pilasters, double Ionian columns flanking the three central axis, and lesenes with emblematic decoration (four emblems symbolizing: commerce and sailing, industry, arts and crafts, agriculture) between high window openings. At the top of the columns, on the cornice between the stories, there are two groups of sculpture - allegories of Art and History. The articulation pattern applied here was repeated on the side elevations - in a simplified form, without sculpture decoration, flat (inter alia, the columns were replaced with pilasters). Apart from the aforementioned carved decorations, the following also command attention in the discussed two elevations: the bronze sculpture of winged Victoria on the top of the portico pediment, semi-nude, other winged female figures with torches topping the attic at the top of the corner pilasters of the façade pseudo-avant-corps, and numerous representations of fantasy figures. Originally, the architectural and carved decorations were supplemented with inscriptions of patriotic nature and quotations from national heroes in the attic panels. ${ }^{17}$

It is clear from the above description that two chief themes can be distinguished in the carved decoration: first - patriotic and historical on the façade -, second - referring to various areas of human activity - ranging from agricultural production, via industrial to artistic and scientific - on the north-eastern elevation. This division seems to reflect two functions for which the building was intended - commemorative and museal. Undoubtedly, the decorations, reaching far beyond their decorative role, constitute a significant element of the building complementing its ideological overtone.

The two symmetrically placed groups of sculptures - allegories of War and Peace - undoubtedly stand out in the view of the façade. They correspond with each other not only as notionally but also formally opposing - they are of similar dimensions, their composition is based on a pyramid, they represent human figures of over-natural size: a woman - personification standing in the centre, surrounded by the other figures, which complement the meaning of

17. At this stage of the research it was impossible to establish the exact content of all the inscriptions. 
the allegories. The sculpture of War (fig. 2) placed on the left side of the portico represents a woman in classically-styled, transparent robe reaching the ground, tied under the bust. ${ }^{18}$ The war-relating attributes include: the armour covering her breasts, the headwear resembling the decoration of Athena's helmet by Phidias, and the long sword supported on the ground, which she apparently holds in her hand. The relatively loose stance in the contrapposto contrasts with the tense face and the wind-blown robe flying above her head like the dangerous currents of history, which introduces unexpected dynamics. The gravity of the figures is also built by symbolical elements - the lowered burning torch ${ }^{19}$ indicating death and darkness ${ }^{20}$ and the massive animal's body lying at her feet. Based only on the visible paw, it is difficult to determine the species of the animal, but the presence of attacking snakes in the composition allows to identify the beast as Hydra. There are figures placed symmetrically on both sides of the figure. The first pair, located directly by her side comprises: a kneeling man, sidewise to the onlooker, covering his face with his hands as a gesture of despair (on the left), and a woman sitting astride Hydra's body, seen in a $3 / 4$ aspect, with a little baby sliding down her forearm. The stance of both of them, who, with despair and conspicuous trust as wellturn towards the woman-War, seems to be surprising. The man leans against her in a familiar gesture seeking consolation, and the woman, with a peaceful facial expression, squinting eyes, turns to her without paying attention to the child, who - perhaps dead - hangs without control with its head downwards. Meanwhile the War, in spite of the hope pinned on her, remains indifferent to human tragedy.

The next figures of the composition are two men situated on both sides of the animal on which the central figure stands. They were depicted while fighting with Hydra's head. The young man on the left, in a semi-squatting position, fiercely defends himself from the beast, trying to avoid being bitten. However, the struggle seems to be lost, as the animal's fangs are already in his hands. The other man, in his prime, in a semi-lying position, although still alive, has already given in to the creature, which has wrapped around his trunk and pierced its fangs into his forearm. Both of them are naked, not prepared to fight for their lifes against dangerous creatures, who they finally fall victim to. Certainly, Hydra is a symbol of the evil brought by the war and which is experienced by everyone - the young and the old, not only soldiers but civilians as well. As in case of the first pair of figures, here, the allegorical figure is indifferent in the face of these dramatic events.

18. This type of robe, tied right under the bust and a nude female bust were formerly applied by Lederer in two of his other personifications: Destiny, from 1896, and Genius of Art, from 1898.

19. In RipA's Ikonologia a lowered torch appears together with an armour as war attributes. CESARE RipA: Ikonologia, Universitas, Kraków, 2002, p. 202.

20. Hans BiedermanN: «Torch», in Leksykon Symboli, Muza, Warsaw, 2001, pp. 301-302. 


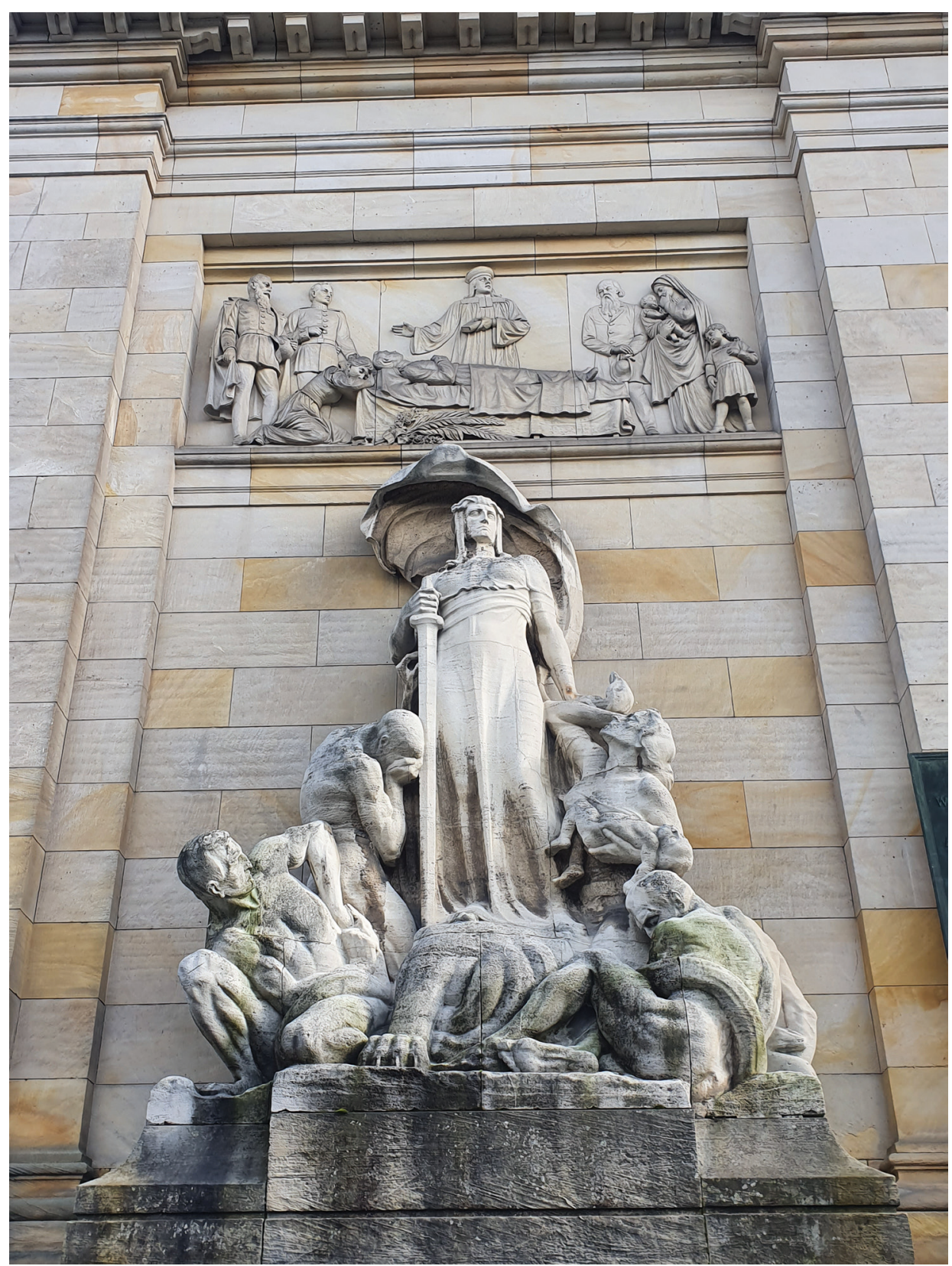

Fig. 2. Hugo Lederer, War, ca. 1900, Upper Lusatian Commemoration Hall with EmperorFriedrich-Museum, Zgorzelec (Görlitz)

Reinhardt Schnauder's relief The Atrocities of War (fig. 3), situated above, is a complement of Lederer's image of war. The symmetrically, academically arranged composition is placed in a horizontally elongated rectangle. In its 
centre, in the foreground there is a catafalque, and the body of a young man wearing military uniform. Inferring from the title of the image, one may assume that this is a soldier who passed away in a war. In front of the coffin a bouquet was placed consisting, among other things, of palm leaves, which can be read in two ways - as a biblical symbol of victory or as a plant connected with death attributed to Hathor, the Egyptian goddess, worshipped in Thebes as the protector of the dead. ${ }^{21}$ In the axis of the composition there is an standing evangelical pastor wearing robes with bands, partly obscured by the catafalque. In his right hand he holds a book, he rises his right hand over the deceased person's head. There are two soldiers at the left edge of the panneau, behind the catafalque headboard. A bearded one, wearing a cuirassier uniform, with a coat flung over his shoulders, respectfully takes off his spiked helmet in the face of the death and presses it against his body. He is recognizable by his characteristic beard as Emperor Friedrich III Hohenzollern. The other man, also bareheaded, is wearing a cuirassier uniform. He is depicted as a young man, without any facial hair or medals. No physiognomical resemblance to any historically know figure, and no distinguishing characteristics may imply that an anonymous brother-in-arms of the deceased person was portrayed. A grief-stricken young woman kneels at the headboard of the catafalque, certainly the wife of the dead soldier. The right end of the composition is filled with a group of other mourners - an elderly man in a frock coat, who holds a hat in his clasped hands, a woman with a little baby in her hands, and a several-year-old girl cuddling up to her. It can be assumed that they are the parents and children of the deceased. The classical outfit of the mother draws attention, contrasting with the contemporary outfits of the other figures, which makes her similar to the Mother of God. In the European culture Mary is perceived as the archetype of a woman, mother, and Mary bewailing Christ's death is one of the topoi, which introduces certain analogy between the biblical scene and the one depicted by Schnauder. While the grief-stricken mother motif shows a certain universalism of the scene, repeated since time immemorial, the figure of Emperor Friedrich III sets it in a specific time framework - the Franco-Prussian War of 1870-1871, during which the Prussian ruler commanded one of the armies and largely contributed to the victory of Germans, and whose end provided impetus to establish the Second Reich. Such an interpretation of war motif combines universal themes with those that contribute to the ideological meaning of the Upper Lusatian Commemoration Hall as a monument of the Emperors and the Unification of Germany. Additionally, the juxtaposition of the intimacy of the scene and its inclusion in the official, patriotic context proves its symbolic character and propaganda dimension. According to the official interpretation, the ones who died at war

21. WiesŁaw Bator: Religia Starożytnego Egiptu. Perspektywa religioznawcza, Wydawnictwo Uniwersytetu Jagiellońskiego, Kraków 2012, p. 300. 
are real patriots, ${ }^{22}$ who devoted their individual interest, their family happiness to the nation, homeland, but this devotion is not invisible to the ruling family.

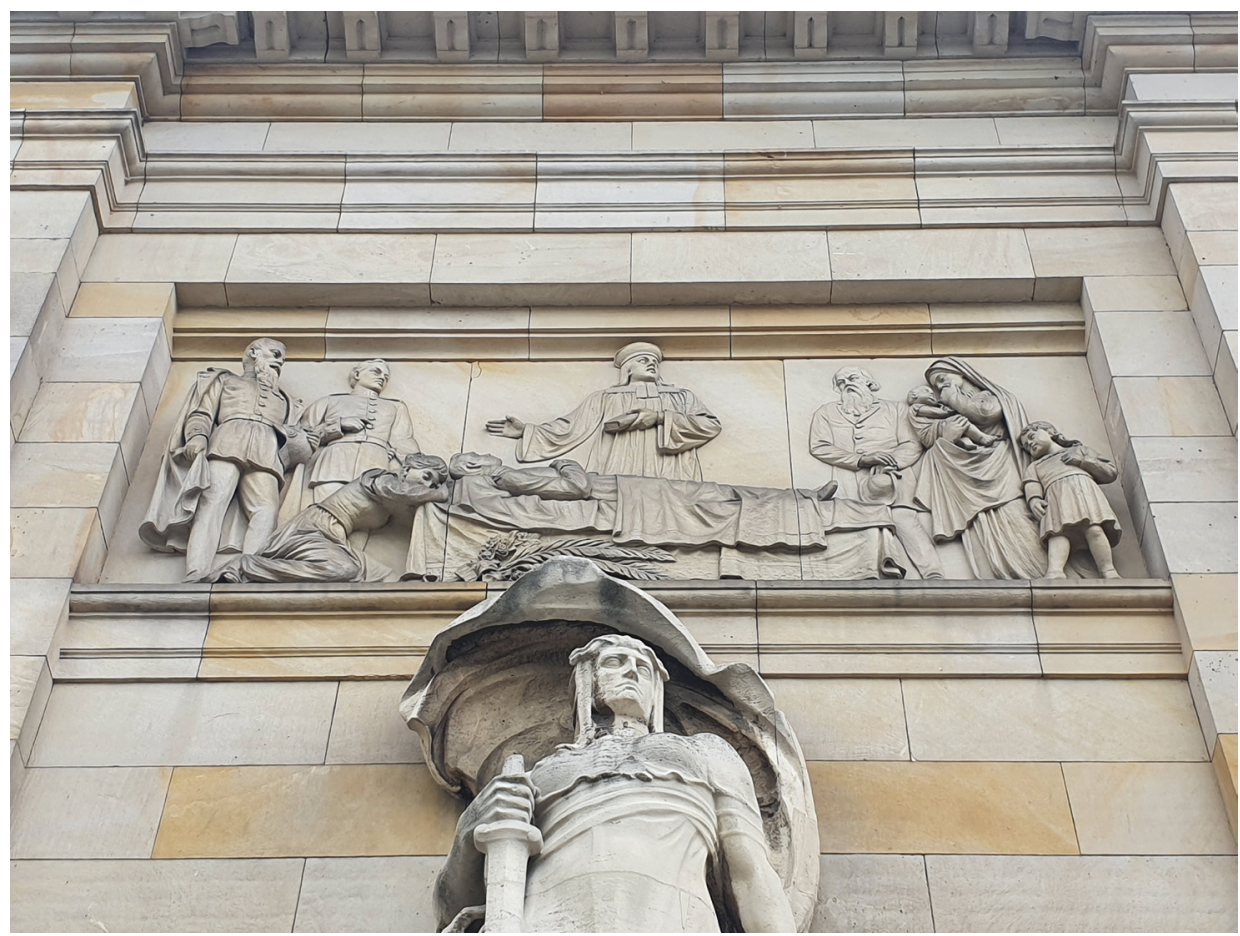

Fig. 3. Reinhardt Schnauder, The Atrocities of War, ca. 1900, Upper Lusatian Commemoration Hall with Emperor-Friedrich-Museum, Zgorzelec (Görlitz)

Interestingly, neither of the war-theme images depicts it directly, no bloody scenes or armed soldiers (exept the Emperor and the man next to him) are seen. Even if the motif of fighting appears, it is treated symbolically (fight with snakes). We learn about the war through its consequences and how it affects individuals or entire families. In spite of the tragic nature of these images, they seem to be a natural consequence with which all the presented characters reconcile themselves, despite the pain. In the context of the entire building, the wars, which gave rise to the emerging national identity, and consequently led to the Unification of Germany, could not have been shown as pointless evil. Analogical narration can be seen in the next pair of images - Peace and The Blessings of Peace.

22. On the changing notion of patriotism in the 19th Germany: TAdeusz J. Żuchowski: Patriotyczne mity i toposy. Malarstwo niemieckie lat 1800-1848, Wydawnictwa Poznańskiego Towarzystwa Przyjaciół Nauk, Poznań 1991, p. 5 ff. 
Peace is personified as a woman wearing a loose, airy robe, standing on a small platform (fig. 4). Her hair is bound, and her temples are decorated with a wreath - probably made of olive branches $-{ }^{23}$ which can be interpreted as the classical symbol of victory, biblical symbol of hope for a better future, or a universal symbol of peace. In her raised hands the woman holds two burning torches, meaning life and light. Although the artist did not decide to add the second typical attribute of peace personification - the horn of plenty,$-{ }^{24}$ the symbolical meaning of the figure is clear. However, the remaining figures of the allegorical composition are completely untypical of images of Peace. The personification is accompanied by five athletically built young men, naked, or partly covered with fabric draped around their waists. Two of them stand directly by her side, one sits at her foot, one lies on the platform with his back turned to the onlooker, and the other seems to be falling having stumbled over the lying one. Two of the men are armed - the sitting one holds a sword, and the one standing on the right holds a scythe, which he is skilfully sharpening. Their bodies are tense, and there is concentration on their faces, they gaze in the distance. The man standing on the left has assumed a similar posture, although not armed, his breast is thrown out and his gesture points at it. All three of them seem to guard the Peace, looking out for the enemy, as if peace was not something given once and for all, and there was a risk of losing it. While a sword is a typical tool of a fighting warrior, a scythe is a piece of farming equipment, used on a short-term basis by peasants in a war. This can be interpreted as the readiness of the entire nation to defend peace. Such attitude may coincide with the Roman proverb $\mathrm{Se}$ vis pacem para bellum ('If you want peace, prepare for war'), according to which there is no peace without being ready to start fighting, whose meaning perfectly matches the militarism of the Second Reich. The man lying on the platform, with his head wrapped in a cloth, face supported on his forearm, hand clenched on his head, one leg backward, the other one tucked under his body, seems to be resting after a great effort, thus he symbolizes the difficulty of achieving peace, not the sacrifices made in achieving it, as it may seem at first glance. However, if the figure is interpreted together with the figure of the man holding an olive branch, one may get the impression that they belong to the consecutive scenes of the same story referring to the story of Pheidippides - the legendary Athenian messenger, who, after the victorious battle of Marathon ran to Athens to announce the victory and warn the Athenians against the approaching Persian fleet. Such an interpretation is contributed by the iconographic similarities with other examples of this theme in the 19th century. ${ }^{25}$

23. An olive branch or wreath woven out of it are attributes of Peace. RipA: op. cit., pp. 325-327.

24. Ibid., pp. 325-327.

25. The works of Schnauder's colleagues: the sculpture Der Siegesbote von Marathon (a naked man with an olive branch in his stretched hand) by Max Kruse (1884), the painting Le soldat de Marathon (1869) by Luc-Olivier Merson, a French painter, or the slightly earlier sculpture by Jean-Pierre-Cortot, a Frenchman, Le Soldat de Marathon annoncant la victorie (1834), might have been the iconographic precursors of the Marathon motif. 


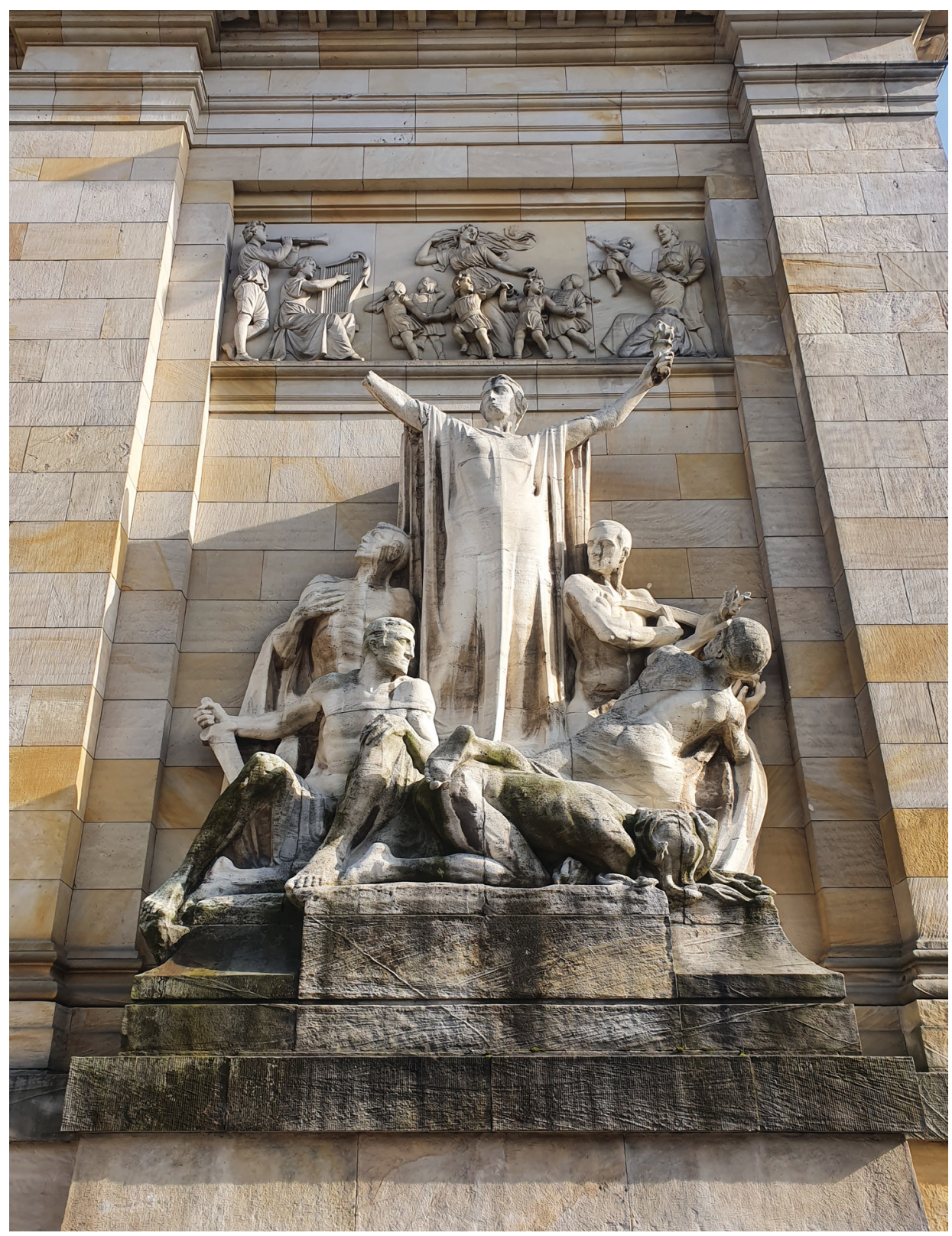

Fig 4. Hugo Lederer, War, ca. 1900, Upper Lusatian Commemoration Hall with Emperor-Friedrich-Museum, Zgorzelec (Görlitz)

The Peace sculpture is reflected by the The Blessings of Peace relief above (fig. 5). Like The Atrocities of War, it has a symmetrical, three-part composition in a horizontally elongated rectangle. The central group comprises a woman wearing a Greek chiton with a coat flying in the wind, holding a several-yearold girl in modern attire, by her hand - the first one in the children's dancing 
procession. The costume lets one interpret the female figure as an allegorical or symbolical one, this may be the eponymous Peace, however, she cannot be unambiguously interpreted due to the lack of attributes. Undoubtedly, the children's dance has a lot of spontaneous joy, serenity, which may be identified with the blessings of peace, such as the music played by two musicians placed on the left side of the composition. These are: a man playing a wind instrument resembling the clarinet, and a woman playing the harp. The last group of figures comprises a kneeling woman holding a baby in her stretched arms, and a man standing behind her and holding his hands on her shoulders as a support gesture. Their intimacy implies that they are the parents of the child, who seems to be a link between the pair of figures and the dancing procession. Iconographically, the gesture of the woman is similar to the gesture of Mary presenting Christ in the temple. Here, the allegorical figure in the centre is the addressee of this action. She and two of the dancing children look towards the baby, whose hands and legs are stretched forward but the head still faces the mother. It is smaller than the other participants of the procession, so it is not likely to join the jolly group, therefore the presentation or entrusting gesture should be interpreted symbolically. While in The Atrocities of War the woman hugs the baby, turning it away from the dramatic scene, here we deal with the opposite gesture. The woman, full of trust, gives the child away to the peaceful world.

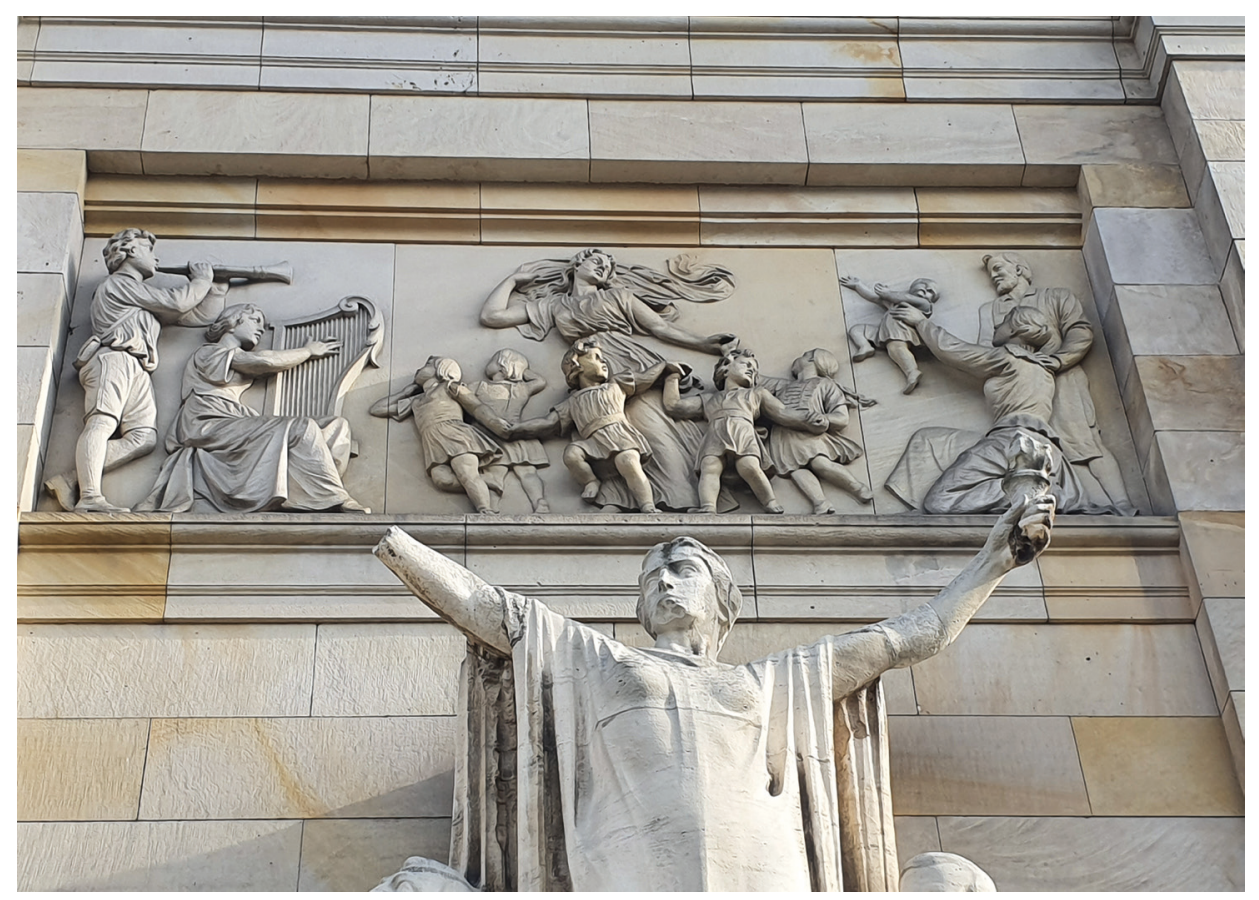

Fig. 5. Reinhard Schnauder, The Blessings of Peace, ca. 1900, Upper Lusatian Commemoration Hall with Emperor-Friedrich-Museum, Zgorzelec (Görlitz) 
Following the 19th century, which abounded with armed conflicts, and the militarism that grew together with the sense of national identity, war and peace seem to be two sides of the same coin. These motifs, just like the motifs of fight and victory, became elements of the Second Reich founding myth. Therefore, apart from the figures of Germania and Victoria, personifications or allegories of these notions appear in the extensive sculpture and architecture structures, erected to venerate the emperors (Wilhelm I and Friedrich III), politicians (Bismarck), generals (Moltke, Roon) or ideas (Unification). Suffice to mention the horse statue of Emperor Wilhelm I in Berlin (1897), the Siegessäule together with the monuments of Bismarck, Moltke and Roon (today at Großer Stern in Berlin) or the monument of the Unification of Germany - Niederwalddenkmal near Rüdesheim am Rhein (1883). However, in case of Lederer's sculpture we deal with a specifically understood peace, which is not a time of carefree, incognizantly accepted prosperity (no horn of plenty attribute), but a value which must be protected and which must be defended. Then the entire building and its extensive iconography, as well as the contributing sculptures on the façade would be a manifestation of the Wilhelmian state's magnitude and power. This thesis can be supported by the selection of the figures for the pantheon inside the Upper Lusatian Commemoration Hall, where the most important figures, apart from the statue of the war-famed emperors depicted in military uniform, there are statues of Bismarck, Moltke and Roon - representatives of the Prussian military state ${ }^{26}$.

\section{BiBLIOGRAPHY}

ANDERS, INES: «Die Oberlausitzer Gedenkhalle mit Kaiser-Friedrich-Museum in Görlitz 1902 bis 1932. Ein Beitrag zu Geschichte und Selbstverständnis der Städtischen Kunstsammlungen Görlitz», in Görlitzer Magazin, 1992, 6 Jhrg, pp. 1-36.

Bator, WiesŁaw: Religia Starożytnego Egiptu. Perspektywa religioznawcza, Wydawnictwo Uniwersytetu Jagiellońskiego, Kraków, 2012.

BedNAREK, ANDREAS: “„Die Ruhmeshalle - patriotisch, edel und schön” Ein Beistrag zur Baugeschichte der Oberlausitzer Gedenkhalle in Görlitz», in Görlitzer Magazin, 1992, 6 Jhrg, pp. 37-49.

BeHr, Hugo: «Die Oberlausitzer Gedenkhalle mit Kaiser Friedrich-Museum in Görlitz», in Deutsche Bauzeitung, 1903, xxxviI Jhrg, n. ${ }^{\circ}$ 61, pp. 393-394, 402-404.

Belzyt, Leszek, Rauterberg, Hans-Werner: «Górne Łużyce od kongresu wiedeńskiego do końca pierwszej wojny światowej (1815-1918)» in BAHLCKE, JoACHIM (ed.): Dzieje Górnych Łużyc. Władza, społeczeństwo o kultura od średniowiecza do końca XX wieku, Wydawnictwo DIG, Warsaw, 2007, p. 203-222.

Biederman, Hans: Leksykon Symboli, Muza, Warszawa, 2001.

CZeKańsKa, KATARZyna: Gmach dawnej Oberlausitzer Gedenkhalle mit Kaiser Friedrich Museum w Zgorzelcu, master's thesis under supervision of Prof. Zofia Ostrowska-Kębłowska at the Art History Institute, University of Wrocław, 2005, not published.

26. Heinrich August Winkler: «Dzieje Niemiec 1806-1933», in Dluga droga na Zachód. Volume 1, Wydawnictwo Uniwersytetu Wrocławskiego, Wrocław, 2007. 
FeyerAbend, Ludwig: Führer durch die Oberlausitzer Gedenkhalle mit Kaiser Friedrich-Museum, Görlitz, 1905.

Oettel, Gunter: Unter der grünen Kuppel. 1, Vom Museum in Görlitz zum Kulturhaus in Zgorzelec, 1904-2004, Taschenbuch, Görlitz-Zittau, 2004.

Ripa, Cesare: Ikonologia, Universitas, Kraków, 2002.

Winkler Heinrich August: «Dzieje Niemiec 1806-1933», in Dtuga droga na Zachód. Volume 1, Wydawnictwo Uniwersytetu Wrocławskiego, Wrocław 2007.

Zehm, Ursula: Die Geschichte des Doppelstandbildes im deutschsprachigen Raum bis zum 1. Weltkrieg mit beschreibendem Katalog, Verlag und Datenbank für Geisteswissenschaften, Weimar, 1995, pp. 27-29

Żuchowski Tadeusz J.: Patriotyczne mity $i$ toposy. Malarstwo niemieckie lat 1800-1848, Wydawnictwa Poznańskiego Towarzystwa Przyjaciół Nauk, Poznań, 1991 